(C) 2021

\title{
Determination of cytotoxicity of germicides and disinfectants on the culture of kidney cells of a calf
}

\author{
Kryvoshyya P. ${ }^{1}$, Rud O. ${ }^{2}$, Lysytsya A. ${ }^{3}$ \\ ${ }^{1}$ Research Station of Epizootology of the Institute of Veterinary Medicine of NAAS \\ 16/18 Kniazia Volodymyra Str., Rivne, Ukraine, 33028 \\ $2,{ }^{3}$ Rivne State University of Humanities \\ 12 Stepana Bandery Str., Rivne, 33028, Ukraine \\ e-mail: ${ }^{1}$ p.kryvoshyya@gmail.com, ${ }^{2}$ oleg.rud-rud1965@ukr.net, 3/ysycya@ukr.net \\ ORCID: ${ }^{10000-0002-8671-6442, ~}{ }^{2} 0000-0003-3153-661 X,{ }^{3} 0000-0001-9028-8412$
}

\begin{abstract}
Goal. To study the cytotoxicity of certain antibacterial preparations used in the treatment of infectious diseases of the urinary system, as well as some disinfectants for calf kidney cell culture. Methods. Cytological, toxic effects test on primary calf kidney cell culture. Determination of the maximum permissible concentrations of antibiotics, antiseptics, and disinfectants that do not yet lead to degeneration of the cell monolayer of calf kidney cells. Results. Tests of some drugs that are often used in veterinary medicine show that the least toxic to calf kidney cells of all tested antibacterial agents are Oxymicol 20 (active substance - oxytetracycline base), Norsulfazole sodium, and Farmazin 50 (active substance - tylosin). Conclusions. These drugs or similar with the same active substances should be used in the treatment of infectious diseases of the kidney and urinary system of cattle and other animals. The possibility of using the method of cultivation and use as test objects of primary cultures of eukaryotic cells in the selection of the optimal composition of therapeutic and prophylactic drugs or disinfectants for veterinary medicine. The obtained results of cytotoxicity can help veterinarians in choosing antimicrobials and disinfectants in terms of their wide range on the market.
\end{abstract}

Key words: veterinary medicine, chemotherapeutic drugs, cell culture, pyelonephritis, antibiotics, polyhexamethylene guanidine.

DOI: https://doi.org/10.31073/agrovisnyk202101-05

An important issue for veterinary medicine is the choice of optimal and at the same time low-toxic drugs for the treatment of various bacterial infections. At the present stage of development of agro-industrial production in the technological process in the cultivation of animals and poultry uses a huge variety of substances for the treatment and prevention of various diseases. The constant search for new drugs and dosage forms continues. One of the areas of modern pharmacology and toxicology is the development of effective methods of biotesting, including methods for determining the cytotoxic effect of drugs on cell cultures [1]. Every year, pharmaceutical companies register and market a large number of new therapeutic and prophylactic drugs. These processes are regulated by codes of quality laboratory (GLP), clinical (GCP) and manufacturing (GMP) practices [2]. GLP or good laboratory practice regulates the study of pharmacological drugs - candidates for drugs in experimental animals to avoid unexpected adverse effects of their use. GCP or good clinical practice regulates a thorough study of pharmacological agents in humans with a guarantee of reliability and reliability of the data obtained with the protection of human rights. Today, the principles of GCP apply to clinical practice in general. GMP or good manufacturing practice ensures the production of medicines in accordance with standards approved by government agencies.

There have been discussions for a long time about the use of laboratory animals for scientific purposes, including in the development and testing of drugs. It should be noted that animal studies, which are conducted to predict the possible negative consequences of the use of drugs, are often criticized. This applies to both ethical standards and the scientific weight of the results [3, 4]. It is believed that with the current development of science, animal experiments can be replaced by computer simulations. Indeed, certain experiments can now be performed in silico that is, using calculations on supercomputers. But such research requires tens of thousands of dollars to pay for the time required by these calculations. It takes months to study the interaction of only two or three molecules in a vacuum or minimal ionic environment. And this is provided that at some stage no error occurs, then this process can take years. It should be born in mind that a living organism consists of many billions of cells and trillions of molecules that coexist in complex relationships, and we don't know exactly about the structure and functions of many of them. Therefore, it is still best to test on living objects.

Animal cell cultures are increasingly used in vitro as biological systems in determining the toxicity of various compounds due to the possibility of control and greater reproducibility compared to test systems in the living organisms. The 3rd International Congress on Alternative Methods in the Use of Animals in the Life Sciences initiated the Good Cell Culture Practice (GCCP), a project developed by the European Centre for the Validation of Alternative Methods [1]. 
In determining the cytotoxicity of certain chemical compounds can be guided by Council Regulation (EC) № 440/2008, which establishes test methods in accordance with Regulation (EC) No 1907/2006 of the European Parliament and of the Council on the registration, evaluation, authorization and restriction of chemicals and Drugs (REACH) of 30 May 2008 [5].

As for cell cultures, of course, it is easier to experiment on them, because they are relatively easy to cultivate, they have a controlled balanced environment and in general the set of influencing factors for them is not so great. Therefore, it is possible to study the action of certain types of molecules, the cytotoxicity of a drug substance or certain drugs, their effect on the processes of mitosis, cell death and so on.

One of the urgent issues of veterinary medicine is the treatment of infectious diseases of the urinary tract, including kidneys (pyelonephritis). Pyelonephritis can be caused by various types of pathogenic flora (bacterial, viral, fungal) of exogenous and endogenous origin. The most common pathogens of pyelonephritis are Escherichia coli, Staphylococcus, Proteus, Enterococcus, Pseudomonas aeruginosa, Streptococcus and others. The main method of treatment is antibacterial therapy (antibiotics, sulfonamides, nitrofurans) [6]. At the same time, in recent decades there has been an increase in cases of resistance of many pathogenic microorganisms, including and Escherichia coli to many broad-spectrum antibiotics [7]. In this situation, it becomes important to select the optimal treatment regimens using the least toxic drugs.

We selected a primary calf kidney cell culture (CKC) as the main test object. Another important argument when choosing this object is that when any drug enters the blood of an animal, it will somehow interact with the kidney cells. In addition, in our opinion, the primary cell culture is a more adequate object of testing than transplanted (transformed). And the lack of costs associated with maintaining transplanted cell cultures reduces the cost of testing.

The purpose of the work. Investigate the cytotoxicity of certain antibacterial drugs used in the treatment of urinary tract infections, as well as some disinfectants, on the culture of calf kidney cells.

Materials and methods of research. Antibacterial drugs (antibiotics, antiseptics, disinfectants): Pharmazin 50 (active substance tylosin, antibiotic of the macrolide group, BIOVET, AD, Bulgaria), Tylosomicol 20 (tylosin tartrate, DEVIE, Ukraine), Ceftiolofifur ), Ceftiodev $5 \%$ suspension for injection (ceftiofur hydrochloride, "DEVIE", Ukraine), Amoxicillin-Astrapharm ( $\beta$-lactam antibiotic amoxicillin, LLC "Astrapharm", Ukraine), Oxymicol 20\% solution for injections (oxytetracycline basis, "DEVIE", Ukraine), Azithromycin Grindeks (antibiotic azalide, groups of macrolide antibiotics), Norsulfazole sodium (LLC "PLUTARH-M", Ukraine), "Polyhexamethylene hydrogens", Ukraine), Glutaraldehyde (Runa Inter LLC, Ukraine), 96\% ethyl alcohol (Medisept, Ukraine), Formalin (37\% formaldehyde solution), Brovadez-20 (alkyldimethylbenzylammonium chloride 20\%, "Brovapharma", Ukraine), Sanidez, tablets (trichloroisocyanuric acid - 55\%; isocyanuric acid - 10\%; excipients: sodium bicarbonate - 30\%; sodium carbonate - 5\%, "Medisept", Ukraine), Thiomersal (merthiolate, organomercury compound, 98\%, Pharm grade, USP, BP).

Determination of cytotoxic effects was performed on primary CKC. Drugs were tested for sterility before biotesting. The studies were performed sequentially in stages: preparation of nutrient media, sowing of cells on microplates and incubation until complete monolayer formation, dilution of test samples and their introduction directly into cell culture in at least 5-10 times, incubation for 3-4 days and accounting results. Primary cell cultures were prepared according to conventional methods [8]. Inoculation of trypsinized cells from embryonic organs was performed at a concentration of 4-6 $\times 10^{5}$ cells per $1 \mathrm{~cm}^{3}$. Determination of cell concentration in the nutrient medium was performed according to our own method using a photoelectrocalorimeter KFK-3 [9]. Cell culture was performed in a mixture of nutrient media 199 and Ihla (1:1) with the addition of $10 \%$ serum of cattle, preheated at $56^{\circ} \mathrm{C}$ for one hour. A mixture of $0.02 \%$ Versen solution and $0.25 \%$ trypsin solution in a ratio of (3:1) was used to obtain a cell suspension for further reseeding. Subcultures were obtained by cell transplantation after monolayer formation after 3-8 days. Cell viability was determined by staining with $0.2 \%$ Trypan blue solution. All cell cultures were tested for the absence of contamination by microorganisms.

After determining the cell concentration and obtaining a seed dose of 400-500 thousand cells/cm ${ }^{3}$ by dilution or concentration, the cell suspension was transferred into 96-well polystyrene plates in a volume of $0.1 \mathrm{~cm}^{3}$. The plates were placed in a special device for cell culture [10]. Kept in a thermostat at $\mathrm{t}=+37^{\circ} \mathrm{C}$ for $2-3$ days, after the formation of the monolayer in the test wells were added drugs diluted on nutrient medium in titers $10^{-1}-10^{-2}-10^{-}$ $3-10^{-4}-10^{-5}$ in a volume of $0.1 \mathrm{~cm}^{3}$. The number of wells of the die for each dilution of the drug was $5-10$. Observations were made by microscopy and evaluation of experimental and control cultures for 3-4 days in order to establish the manifestation or absence of cytotoxic effects. The degree of cytotoxicity was determined by changes in cell morphology (rounding, shrinkage of cells, separation from the surface of the wells of cells that have undergone degenerative changes). For the maximum concentration of the drug was taken the largest amount, which has not caused yet the degeneration of monolayer cells. To obtain reliable results, the following requirements were met: cell culture was without changes in the external structure of cells and the monolayer as a whole, during and at the beginning of the study did not change the components of nutrient media, studies were performed on cell culture obtained from the same organ animals.

Research results and their discussion. Microscopy and evaluation of experimental and control cultures to determine the manifestation or absence of cytotoxic effects of the studied antibacterial drugs allowed to determine their maximum allowable concentrations (MAC) for primary CKC. The table 1 shows the MACs that did not cause degeneration of the cell monolayer and minimum bactericidal concentrations (MBC), number of replicates are $n$ $=5-10$. 


\section{Cytotoxicity act of antibacterial chemotherapeutics to the primary culture of CKC}

\begin{tabular}{|c|c|c|c|c|c|c|}
\hline The drug or its & \multicolumn{4}{|c|}{ Concentration, $\mu \mathrm{g} / \mathrm{cm}^{3}$} & MAC, & MBC for E. coli, \\
\hline Pharmazin 50 & 5000 & 500 & 50 & 5 & 500 & $\geq 14$ \\
\hline Action on the monolayer & + & - & - & - & & \\
\hline Tylosomicol 20 & 5000 & 500 & 50 & 5 & 50 & $\geq 14$ \\
\hline Action on the monolayer & \pm & \pm & - & - & & \\
\hline Ceftiofur hydrochloride & 1000 & 100 & 10 & 1 & 10 & $1.0-1.5$ \\
\hline Action on the monolayer & + & \pm & - & - & & \\
\hline Ceftiodev 5\% & 20000 & 2000 & 200 & 20 & 200 & $1.0-1.5$ \\
\hline Action on the monolayer & + & \pm & - & - & & \\
\hline Amoxicillin & 15000 & 1500 & 150 & 15 & 150 & $1.0-10$ \\
\hline Action on the monolayer & + & \pm & - & - & & \\
\hline Oxymicol 20 & 10000 & 1000 & 100 & 10 & 1000 & $0.1-6$ \\
\hline Action on the monolayer & + & - & - & - & & \\
\hline Azithromycin & 10000 & 1000 & 100 & 10 & 10 & for E. coli not usually \\
\hline Action on the monolayer & + & \pm & \pm & - & & $\begin{array}{c}\text { used, for resistant } \\
\text { strains of Neisseria } \\
\text { gonorrhoeae } \geq \mathrm{MBC}= \\
0.5 \mu \mathrm{g} / \mathrm{cm}^{3}\end{array}$ \\
\hline Norsulfazole sodium & 500 & 50 & 5 & 0.5 & 500 & - \\
\hline Action on the monolayer & - & - & - & - & & \\
\hline
\end{tabular}

$\mathrm{P} \leq 0.05$

Note: "-" - a monolayer of cells without changes; " \pm " - there are separate areas of cell degeneration; "+" - the monolayer is destroyed, cell death (after 96 hours).

No degenerative changes in the monolayer were observed at 96 hours at MAC and lower concentrations in cell cultures, and all cell lines retained the ability to be further cultured. Concentrations above the MAC after 2448 hours caused degeneration of the monolayer in the cell lines: the cells were rounded, separated from the surface of the wells, the $\mathrm{pH}$ of the medium was shifted to the acidic side. Thus, doses of higher MAC showed signs of cytotoxic effects. Oxymicol 20, Norsulfazole sodium and Pharmazin 50 were the least toxic for CKC of all tested antibacterial agents. Antibiotics amoxicillin and tylosin belong to the moderately dangerous substances (Danger class 3 is in accordance with GOST 12.1.007); they are active substances in the drugs Amoxicillin and Pharmazin 50. But their MAC on calf kidney cell culture differed significantly. Thus, the toxicity of Amoxicillin was 3.33 times higher for CKC compared with the toxic effects on these cells of Pharmazin 50.

The results of cytotoxicity testing of individual disinfectants and antiseptics are given in table 2.

\section{Cytotoxicity act of disinfectants to the primary culture of CKC}

\begin{tabular}{|c|c|c|c|c|c|}
\hline \multirow{2}{*}{$\begin{array}{l}\begin{array}{c}\text { Commercial name of the drug or } \\
\text { active substance }\end{array} \\
\text { Glutaric aldehyde }\end{array}$} & \multicolumn{4}{|c|}{$\begin{array}{l}\text { The concentration of the drug / state of the } \\
\text { monolayer of cells after } 96 \text { hours }\end{array}$} & \multirow{3}{*}{$\begin{array}{c}\begin{array}{c}\mathrm{MAC}, \\
\mathrm{mg} / \mathrm{cm}^{3}\end{array} \\
0.25 \\
\mathrm{mg} / \mathrm{cm}^{3}\end{array}$} \\
\hline & $\begin{array}{l}2500 \\
\mathrm{mg} / \mathrm{cm}^{3}\end{array}$ & $\begin{array}{c}2.5 \\
\mathrm{mg} / \mathrm{cm}^{3}\end{array}$ & $\begin{array}{c}0.25 \\
\mathrm{mg} / \mathrm{cm}^{3}\end{array}$ & $\begin{array}{c}0.03 \\
\mathrm{mg} / \mathrm{cm}^{3}\end{array}$ & \\
\hline Action on the monolayer & + & + & - & - & \\
\hline Ethyl alcohol 96\% & $0.96 \%$ & $0.1 \%$ & $0.01 \%$ & $0.001 \%$ & \multirow[t]{2}{*}{1.0} \\
\hline Action on the monolayer & + & - & - & - & \\
\hline Brovadez-20 & $\begin{array}{l}200000 \\
\mathrm{mg} / \mathrm{cm}^{3}\end{array}$ & $\begin{array}{l}20000 \\
\mathrm{mg} / \mathrm{cm}^{3}\end{array}$ & $\begin{array}{c}2000 \\
\mathrm{mg} / \mathrm{cm}^{3}\end{array}$ & $\begin{array}{c}200 \\
\mathrm{mg} / \mathrm{cm}^{3}\end{array}$ & \multirow[t]{2}{*}{0.2} \\
\hline Action on the monolayer & + & + & + & - & \\
\hline Formaldehyde & $\begin{array}{c}3700 \\
\mathrm{mg} / \mathrm{cm}^{3}\end{array}$ & $\begin{array}{c}370 \\
\mathrm{mg} / \mathrm{cm}^{3}\end{array}$ & $\begin{array}{c}37 \\
\mathrm{mg} / \mathrm{cm}^{3} \\
\end{array}$ & $\begin{array}{c}3.7 \\
\mathrm{mg} / \mathrm{cm}^{3} \\
\end{array}$ & \multirow[t]{2}{*}{0.004} \\
\hline Action on the monolayer & + & + & + & - & \\
\hline Sanidez & $1 \%$ & $0.1 \%$ & $0.01 \%$ & $0.001 \%$ & \multirow[t]{2}{*}{0.1} \\
\hline Action on the monolayer & + & + & - & - & \\
\hline Thiomersal (merthiolate) & $1 \%$ & $0.1 \%$ & $0.01 \%$ & $0.001 \%$ & \multirow[t]{2}{*}{0.1} \\
\hline Action on the monolayer & $\mathrm{n} / \mathrm{i}$ & $\mathrm{n} / \mathrm{i}$ & - & - & \\
\hline $\begin{array}{l}\text { Polyhexamethylene } \\
\text { hydrochloride (PHMG) }\end{array}$ & $0.1 \%$ & $0.01 \%$ & $0.001 \%$ & $0.0001 \%$ & \multirow[t]{2}{*}{0.001} \\
\hline Action on the monolayer & + & + & + & - & \\
\hline
\end{tabular}

$\mathrm{P} \leq 0.05$ 
Note: "-" - a monolayer of cells without changes; " \pm " - there are separate areas of cell degeneration; "+" monolayer destroyed, cell death (after 96 hours), "n/i" - not investigated.

Ethyl alcohol and glutaraldehyde were found to be the least toxic to CKC of all disinfectants and antiseptics tested. However, Polyhexamethylene guanidine hydrochloride (PHMG), which has proven itself as an effective disinfectant [11, 12], when ingested was a fairly cytotoxic drug. An example of the destruction of the monolayer of CKC under the action of PHMG is shown in Fig.

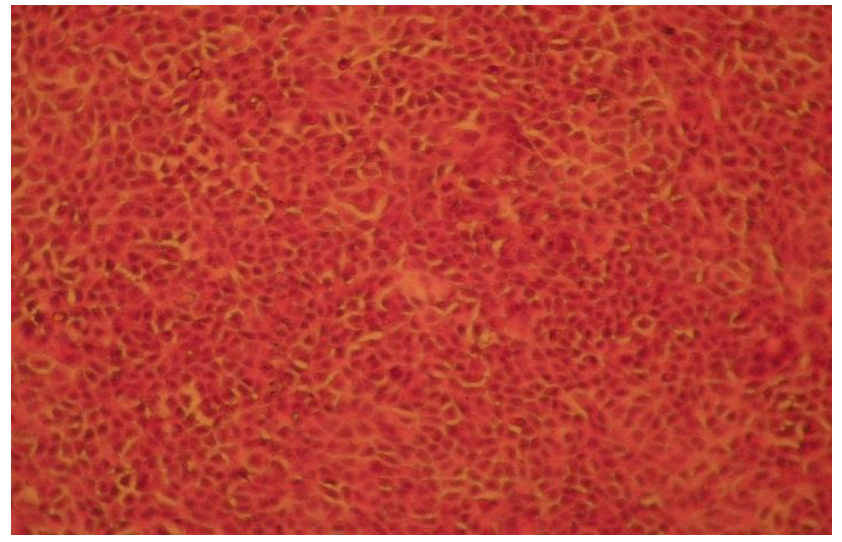

a

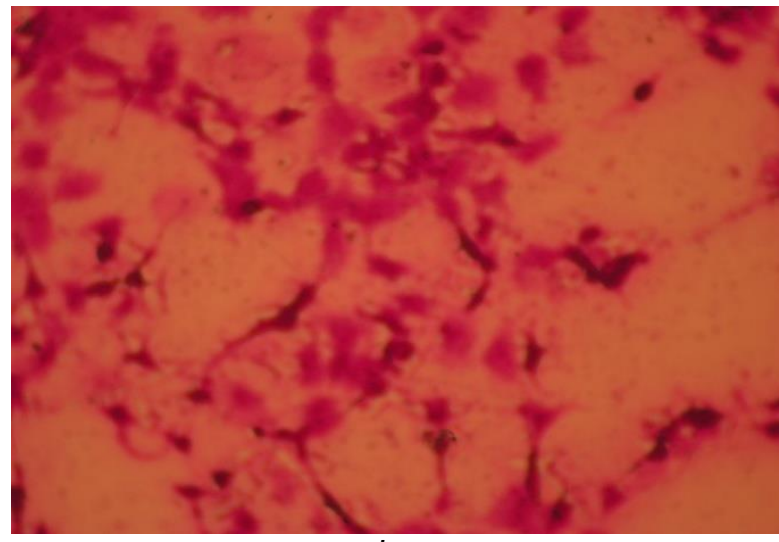

$b$

The result of the action on the primary culture of calf kidney cells: a - monolayer treated with PHMG at a concentration of $10^{-4} \%$; $b$ - destruction of the monolayer of treated PHMG at a concentration of $10^{-3} \%$, the manifestation of cytotoxic effects of the drug; $\times 400$

\section{Conclusions}

Our researches have shown that the least toxic to the primary culture of calf cells of all tested antibacterial agents were Oxymicol 20 (active substance - oxytetracycline), Norsulfazole sodium and Pharmazin 50 (active substance - tylosin). Since these drugs have sufficient antibacterial activity, their use in the treatment of infectious diseases of the urinary tract of both cattle and other animals are justified. In the future, it is advisable to try other drugs used to treat pyelonephritis (trimethoprim / sulfamethoxazole, ciprofloxacin, ampicillin, etc.). Thus, the least toxic antibiotics, disinfectants and antiseptics among those most commonly used in veterinary medicine were identified in the primary test culture of calf kidney cells. However, it should be recognized that none of the isolated cell cultures will have the same environment as in a living organism. There is a problem of determining the systemic action and taking into account the environment. Therefore, it is impossible to completely abandon experiments on a multicellular organism, which gives much more information than an experiment on cells cultured outside the body.

Of course, the results obtained on cell cultures may not be completely equivalent to the processes characteristic of whole organisms. Therefore, such tests will always have some discrepancies with reality. In this regard, it would be more correct to use organelles - artificially grown in the laboratory multicellular threedimensional structures (3D), which reproduce certain properties of individual organs (but not organ systems). Thus, it is possible to study the effect of drugs not on individual cells or individual groups of cells, but on cell systems, investigating changes in their interactions.

Another possible area of application is pharmaceutical and genetic. Having determined the individual sensitivity of cells isolated from representatives of certain breeds of animals, populations, you can choose the most adequate and least harmful therapeutic and prophylactic drugs.

\section{References}

1. Hartung, T., Gstrauntheler, G., Coecke, S. et al. (2001). Good cell culture practice (GCCP) - an initiative for standardization and quality control of in vitro studies. The establishment of an ECVAM Task Force on GCCP. ALTEX, 1(18). 75-78.

2. Abduieva F.M., Bychkova O.lu., Bondarenko I.O. et al. (Yabluchanskoho M.I., Savchenka V.M. (Ed.)) (2011). Klinichna farmakolohiia: Pidruchnyk dlia studentiv i likariv [Clinical Pharmacology: A Textbook for Students and Physicians]. Kharkiv: KHNU V.N. Karazina. [in Ukrainian].

3. Barnard, N. D., \& Kaufman, S. R. (1997). Animal research is wasteful and misleading. Scientific American, 276(2). 80-82. doi: 10.1038/scientificamerican0297-80

4. Cohen, M. J., Kaufman, S. K., Ruttenberg, R., \& Fano, A. (1998). A critical look at animal experimentation. Medical Research Modernization Committee, 1 - 15.

5. Council Regulation (EC) No 440/2008 of 30 May 2008 laying down test methods pursuant to Regulation (EC) No 1907/2006 of the European Parliament and of the Council on the Registration, Evaluation, Authorisation and Restriction of Chemicals (REACH) (Text with EEA relevance). 
6. Shuliak, O.V. (2014). Infektsii sechostatevykh shliakhiv: piielonefryt [Genitourinary tract infections: pyelonephritis]. Ukrainian medical journal, 4(102), 32-42. [in Ukrainian].

7. Colgan, R., Williams, M., \& Johnson, J. R. (2011). Diagnosis and treatment of acute pyelonephritis in women. American family physician, 84(5). 519-526.

8. Dyakonova, L.P. (2009). Metody i primeneniye $v$ biotekhnologii [Methods and Applications in Biotechnology]. Moscow: Sputnik+. [in Russian].

9. Kryvoshyia, P.lu., Kot, L.B., \& Mandyhra, M.S. (2003). Pat. № 62119 Ukraina, MPK GOIN 21/00. Sposib vyznachennia kontsentratsii klityn pereshchepliuvanoi kultury trakhei teliaty za dopomohoiu fotokalorymetrychnoho pryladu [Method of determining concentration of cells of transplanted calf tracheal culture using photocalorimetric device]. Patent 62119 of Ukraine. [in Ukrainian].

10. Kryvoshyia, P.lu., \& Liash, S.lu. (2012). Sposib kultyvatsii klityn u chashkakh Petri ta polistyrolovykh plashkakh [Method of culturing cells in Petri dishes and polystyrene plates]. Patent 67895 of Ukraine. [in Ukrainian].

11. Lysytsia, A.V., Mandyhra, M.S., Kryvoshyia, P.lu. et al. (2013). Kompleksna diia polimernykh pokhidnykh huanidynu na klitynni kultury. Veterynarna biotekhnolohiia [Complex action of polymeric derivatives of guanidine on cell cultures]. Veterinary biotechnology, 22, 328-337. [in Ukrainian].

12. Lysytsia, A.V., Mandyhra, Yu.M., Boiko, O.P. et al. (2015). Dyferentsiina chutlyvist mikroorhanizmiv do poliheksametylenhuanidynu [Differential sensitivity of microorganisms to polyhexamethylene guanidine]. Microbiological Journal, 77(5), 11-19. [in Ukrainian]. 